\title{
UPSURGE OF A NEW ALCOHOLIC FUEL ERA FOR TRANSPORT SECTOR IN INDIA, IN THEFORM OF ETHANOL
}

\author{
Porag Kalita ${ }^{1}$ \\ ${ }^{1}$ Head: Automobile Engineering Department, Vocational Education (+2), Govt of India, M R S Higher Secondary \\ School, Titabor, Jorhat, Assam, India - 785630
}

\begin{abstract}
The search is on for ways to marry the twin goals of economic development and environmental protection, one of the most promising strategies could be the use of ethanol as a renewable fuel to reduce environmental pollution from India's transport sector while creating new jobs in rural communities. Ethanol as a gasoline blend has helped to reduce dependence on oil import and harmful vehicular emission and improve the rural economy. Since ethanol is produced from biomass such as sugarcane, molasses and grains, its widespread use has led to higher biomass yield, rural economy and growth in Industry. The main aim of this paper:

1) Economic and Environmental benefits of use ethanol in India,

2) How ethanol use has helped to improve environmental quality and promote economic development, etc.

So far, the discovery of fossil fuel reserves has more than kept pace with demand. Known resources now exceed a trillion (1012) tones in total compared with just over half this amount 30 years ago. Hydrocarbons get heavier, they become less volatile, and these heavier fractions make excellent liquid fuels for Cars, Lorries and Aircraft respectively. With this in mind, Ethanol, Methanol, Easter and Hydrogen are the principal renewable contenders. In the last decades, technological advances have lowered the cost of producing high quality fuels and chemical products from plant matter, while environmental regulations have raised the cost of manufacturing and using petroleum derived products, mounting evidence of the potential contribution of gasoline and diesel combustion to global climate interest in long term, sustainable fuel solutions for the transport sectors. Stakeholders, who were once adversaries, are today, working together, to move toward a "renewable energy" future.
\end{abstract}

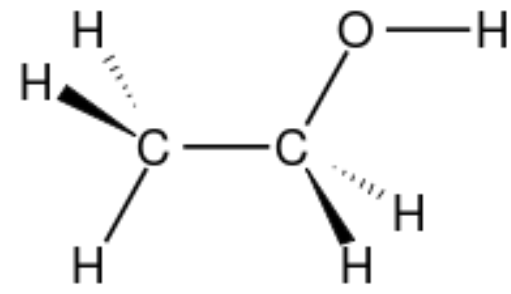

Structure of ethanol molecule that all bonds are single bonds

During ethanol fermentation, glucose and other sugars in the corn (or sugarcane) are converted into ethanol and carbon dioxide.

$$
\mathrm{C}_{6} \mathrm{H}_{12} \mathrm{O}_{6} \rightarrow 2 \mathrm{C}_{2} \mathrm{H}_{5} \mathrm{OH}+2 \mathrm{CO}_{2}+\text { heat }
$$

During combustion ethanol reacts with oxygen to produce carbon dioxide, water, and heat:

$$
\mathrm{C}_{2} \mathrm{H}_{5} \mathrm{OH}+3 \mathrm{O}_{2} \rightarrow 2 \mathrm{CO}_{2}+3 \mathrm{H}_{2} \mathrm{O}+\text { heat }
$$

\section{INTRODUCTION}

Increased energy consumption has often been used as an indicator for economic growth. While economic and social development is not possible without the use of energy, the process of development determines to a large extent the pattern and levels of energy use.
The present strategy worldwide is to opt for cleaner fuels, which are renewable as well as environmental friendly. Today, fuel ethanol accounts for roughly two-third of the world ethyl alcohol production. India is a fourth largest production of ethanol in the world, yet it has not been able to utilize even one percent of this production as transport fuel. 
India's oil import level, expected to rise above 100 million tones over the next two or three year's is going to result in greater foreign exchanges outflow.

As per experimental study, ethanol fuel can improve urban air quality and reduce emission of green house gases. Ethanol is used in blends with gasoline at 10:85 in volume (E10, E85), which contain about 3.5 percent with of oxygen. Usually, the blends are obtained by 'splash' blending ethanol with unleaded gasoline, already in the distribution systems to meet the requirements for higher-grade gasoline.

As an oxygenate (ethanol contains 35 percent oxygen by weight), fuel ethanol enhances the combustion of gasoline, resulting in a more efficient burn and greatly reduced emissions. If helps minimize oil pollutants, including hydrocarbons. Nitrogen di-oxide (NOx), Carbon di-oxide, and toxic.

Ethanol has been widely uses as an additive in gasoline, recent development have made the ethanol diesel blend on interesting new alternative for conventional, unmodified diesel vehicles. A new additive allows ethanol to be splash blended with diesel fuel.

Sugar and distillery industries being complementary to each other's are the major players in the ethanol sector. The rate of the Government therefore, is critical in defining policies favoring these industries.

The by far largest fraction of the global ethanol production, however, is produced by fermentation

\section{LITERACY REVIEW}

The Brazilians run their cars on ethanol made from sugar cane. Americans make ethanol from surplus gain. In Europe, rapeseed oil converted into esters and the liquid is used as a substitute for diesel fuel in buses and boats.

As a part of the clean fuel intervention programs, the Government of India has introduced unleaded fuel and allowed the use of CNG to keep pollution in check. However, the completely ignored ethanol in all its programmes for field implementation. There are no technical barriers to prevent the widespread introduction of ethanol policy- related issues are the role of State and Central government agencies, including ethanol availability, supply, mixing, distribution and its use in automobile engines.

In India primarily depends on molasses based distilleries for supply of ethanol, which is largely produced in States such as Uttar Pradesh, Tamilnadu, Assam and it help if these states initial action in declaring polices for ethanol use in the transport sector.

Incidentally, the variation in tax and duty structure has affected the cost of ethanol in the different states, which also influences inter- state movement and slows down policy initiative.
The current installed capacity of ethanol production can easily meet the gasoline demand of the transport sector for a 10 percent blend. Converting sugarcane juice directly to ethanol is another option to increase its production.

Sugar production is expected to grow of 5 percent per annum with a corresponding increase in ethanol production. The growth of potable industry will not be more than the current population growth rate (2.1 percent per annum), which thus leaves excess ethanol devoid of market outlets even after meeting the demands of the potable and chemical industry.

Since there is scope for converting sugarcane directly into ethanol, policy measures can be taken allowing the direct route of conversion to meet any high demand. More than 1,000 million liters of ethanol can be produced directly from sugarcane juice using less than 1.5 million tones of sugarcane. However, for short-term application of ethanol as fuel, the present installed capacity of the country can suffice to meet the need.

\subsection{Solution of Problem}

1. The coming decades will find several fuels competing for markets currently dominated by Gasoline.

2. Gaseous fuels such as CNG and LPG are in use as vehicular fuels in our country to reduce urban pollution. However, these fuels require large investment in terms of infrastructure and vehicle kit.

3. Adoption of new ethanol production technologies and development of new automobile engines, sales and service network etc. represent the important of forward linkage, where as sugarcane productivity with employment opportunities and enhancement of rural purchasing power constitute backward linkage, etc.

\section{METHODOLOGY (ENGINE PERFORMANCE BY ETHANOL)}

In Brazil, there are four million cars running by ethanol. Other millions cars which have been burns a mixture of $20 \%$ ethanol and $80 \%$ petrol by volume.

Ethanol's higher octane rating allows an increase of an engine's compression ratio for increased thermal efficiency. 


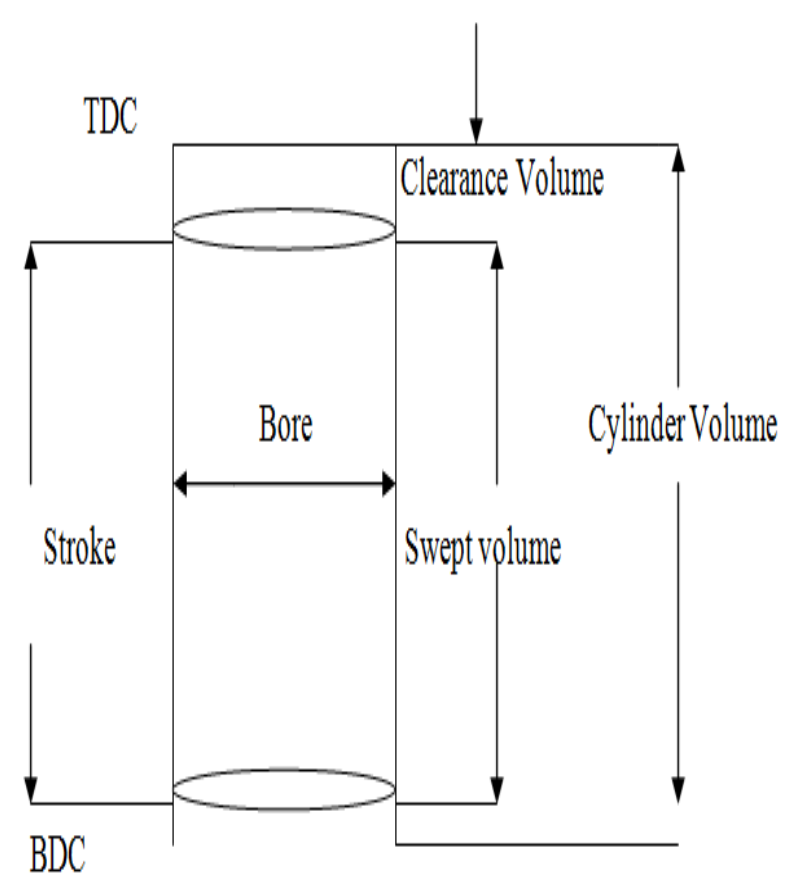

Fig 1: Technical Term.

TDC: Top Death Centre

BDC: Bottom Death Centre

The size in $\mathrm{mm}$ of the engine cylinder is termed its bore. The distance between TDC and BDC of the piston travel is known as a stroke.

The volume covered by the piston as it moves from BDC to TDC, is known as swept volume on piston displacement.

Numerically, piston displacement: $\pi \mathbf{r}^{2} \times \mathbf{L} \times \mathbf{N}$

Where,

r- radius of the cylinder bore,

L- Length of the stroke,

N- Number of cylinders,

II- a constant,

And, swept volume $=$ Piston displacement

$$
=\pi / 4 \times \mathrm{D}^{2} \times \mathrm{L} \times \mathrm{N}
$$

\section{Here, D- Diameter of Bore.}

An experimental was conducted in Maruti $800 \mathrm{cc}$ with ethanol (20\%) and Petrol (80\%) by mixture as fuel.

For,
M 800cc,
D- $6.85 \mathrm{~cm}$,

L- $7.2 \mathrm{~cm}$,

Swept Volume $=\pi / 4 \times(6.85)^{2} \times 7.2 \times 3$

$$
\begin{aligned}
& =796 \mathrm{~cm}^{3} \\
& =800 \mathrm{cc}(\text { nearly })
\end{aligned}
$$

Clearance Volume: For the meaning of clearance volume to ethanol and petrol mixture, it is determines in the cylinder when the piston is at TDC is termed clearance volume. In fact, clearance volume is the combustion chamber volume.

Compression Ratio: It is the ratio between the total volumes of ethanol fuel mixture in the cylinder when the piston is at BDC to the volume when the piston is at TDC.

Compression Ratio $=$ Swept volume + Clearance volume

Clearance Volume

\section{RESULT}

1) Ethanol Petrol mixture for compression ratio fixed by 8.5: 1 in 800cc. however, high compression ratio enables the fuel ignite easily.

2) Less detonation, because abnormal combustion causes detonation, as a result give out large amounts of NOx produced. However, ethanol fuel mixture has less produce Nox, $\mathrm{CO}$ gases i.e. green. Etc.

3) Theoretical Heat cycle: (Actual Otto Cycle). This is the expression of ethanol standard efficiency of the Otto cycle. This efficiency depends upon the compression ratio, which is the ratio of total cylinder volume and clearance volume. It depends upon the ignition characteristics of petrol ethanol mixture as well as low octane petrol wills self-ignited during compression. The actual Otto cycle the following:

a) The expansion and compression processes do not take place exactly adiabatically,

b) Heat is added and rejected not necessarily at constant volume,

c) The mass of the gas during expression and compression strokes varies invariably,

d) The combustion changes the chemical composition of the gas largely.

e) Thus, the specific heat of the gas does not remain constant.

f) The exhaust gases do not return to their original condition and are rejected to the atmosphere. The actual Otto cycle is truly an open cycle and not a close one. Etc. 


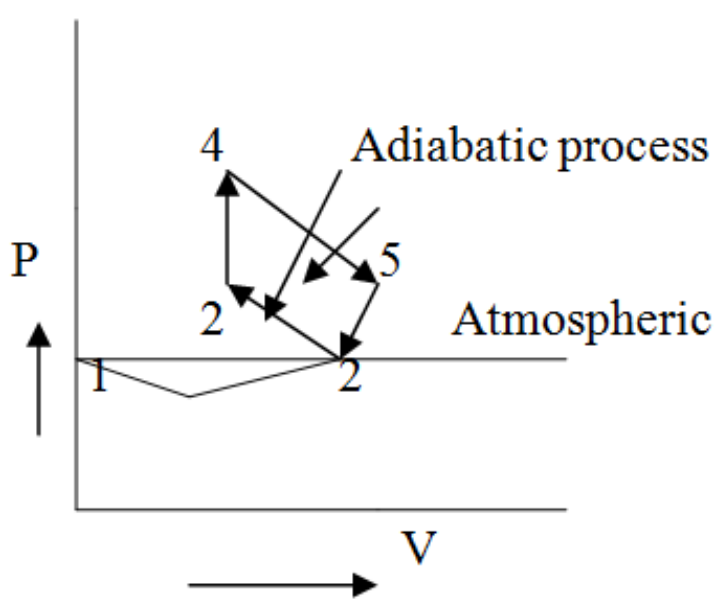

Fig 2: Ideal Otto Cycle (Petrol)

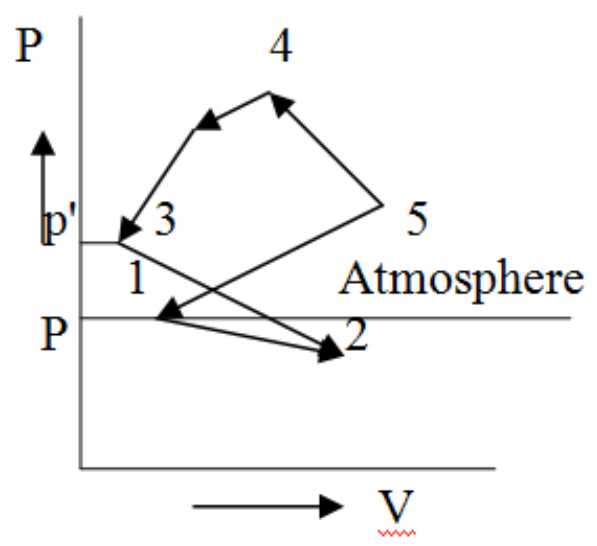

Fig 3: Actual Otto cycle

\section{POWER BALANCE}

Power balance for three cylinder engine to use ethanol and M800 is consists by three cylinder.

In such engines, the crankshaft is designed such that the crankpins are $120^{\prime}$ apart and the firing interval is given below-

Firing interval $=720^{\prime} / 3 \quad\left(1\right.$ revolution of crankshaft $\left.=360^{\prime}\right)$

$$
=240^{\prime} \quad\left(2 \text { revolution of crankshaft }=720^{\prime}\right)
$$

Crank pins arranged by following way-
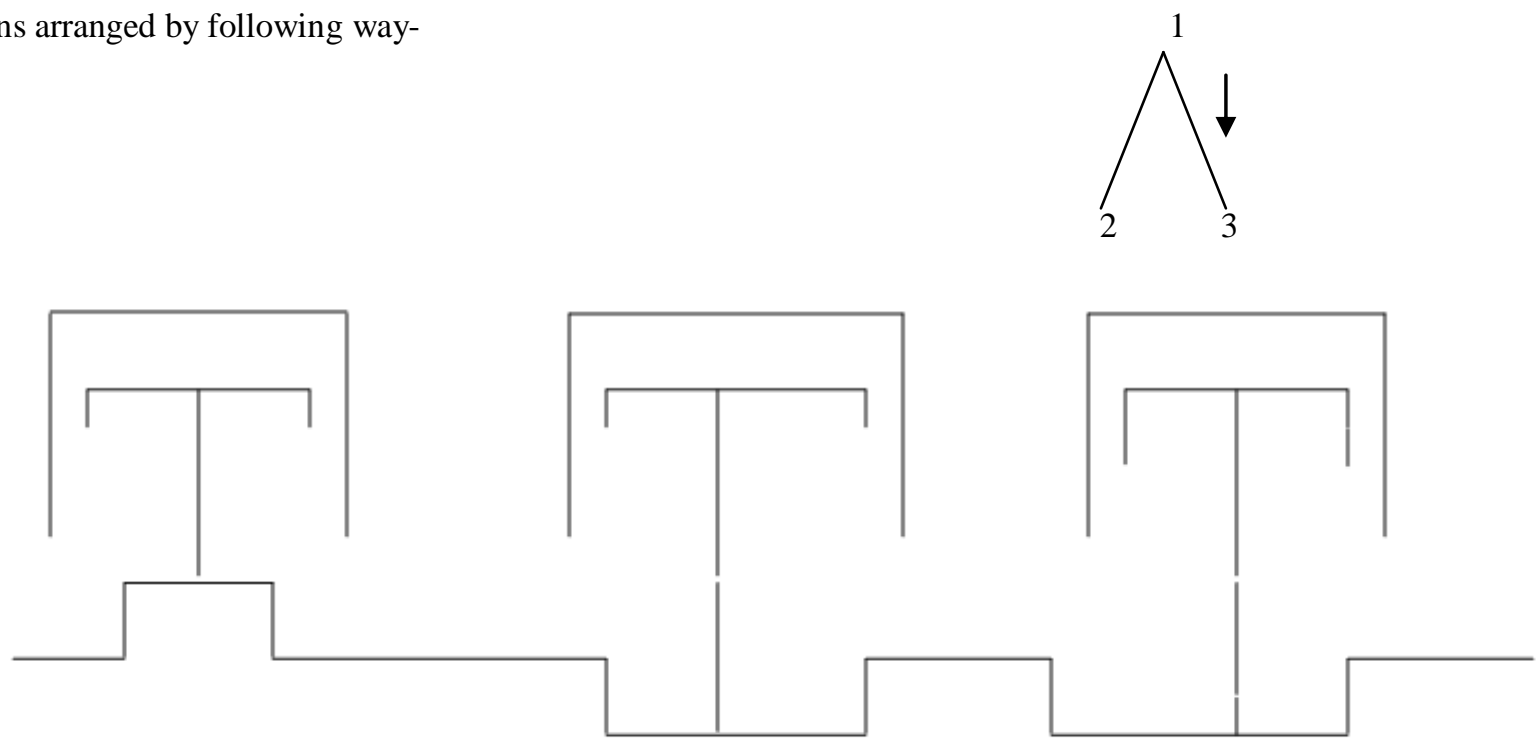

Fig 4: Crankpin arrangement (three-cylinder engine)

Firing Order- cycle of operation i.e. 2 revolution of the crankshaft.

One revolution of the crankshaft One revolution of the

360'

One stroke one stroke

Or $180^{\prime}$ or $180^{\prime}$

$60^{\prime} 60^{\prime} 60^{\prime}$

$60^{\prime} 60^{\prime} 60^{\prime}$ crankshaft 360'

$\begin{array}{ll}\text { one stroke } & \text { one stroke } \\ \text { or } 180^{\prime} & \text { or } 180^{\prime}\end{array}$

$60^{\prime} 60^{\prime} 60^{\prime} \quad 60^{\prime} 60^{\prime} 60^{\prime}$
Cylinder No $1 \quad \mathrm{P} \quad \mathrm{P} \quad \mathrm{P}$
E E E
C P P
S S S
Cylinder No 2 S C C
S S C
PEE
$\mathrm{C} \mathrm{C} \mathrm{P}$
C C C
E S S
P P E

Table: Power Balance (Three-cylinder engine) 


\section{TYPE OF DATA}

The coming decades will find several fuels competing for markets currently dominated by Gasoline. Gaseous fuels such as CNG and LPG are in use as vehicular fuels in our Country to reduce urban pollution control. However, these fuels require large investment in terms of infrastructure and vehicle kit.

Today fuel ethanol accounts for roughly two third of the world ethyl alcohol production. In India is the fourth largest producer of ethanol in the world.

\begin{tabular}{|l|l|}
\hline & Brazil \\
\hline Ethanol production (Hydrous \& Anhydrous) & 13.5 billion liters Gasohol: 24\% Ethanol, 70\% gasoline \\
\hline & India \\
\hline Ethanol Productive & 2.7 billion liters \\
\hline
\end{tabular}

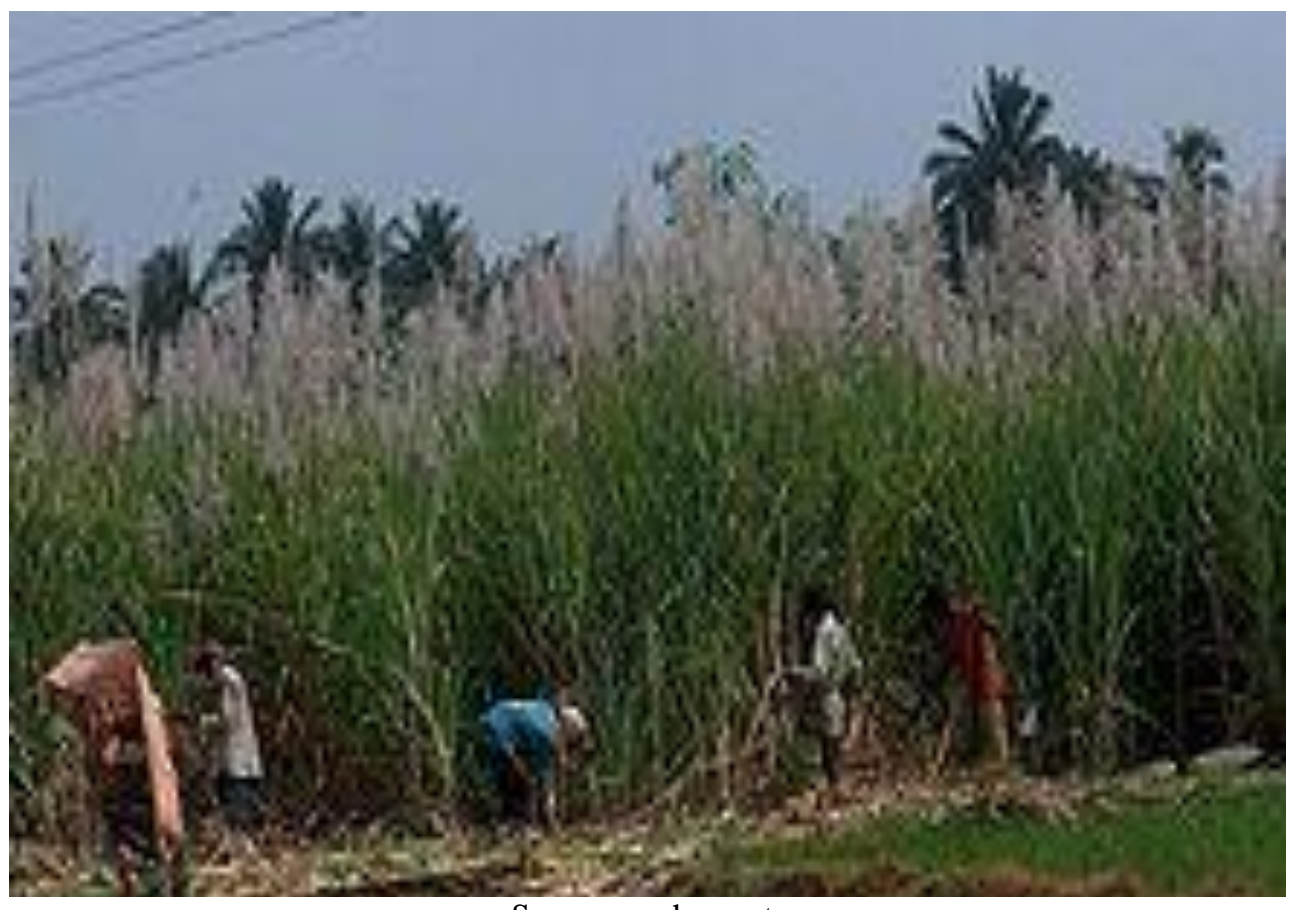

Sugar cane harvest

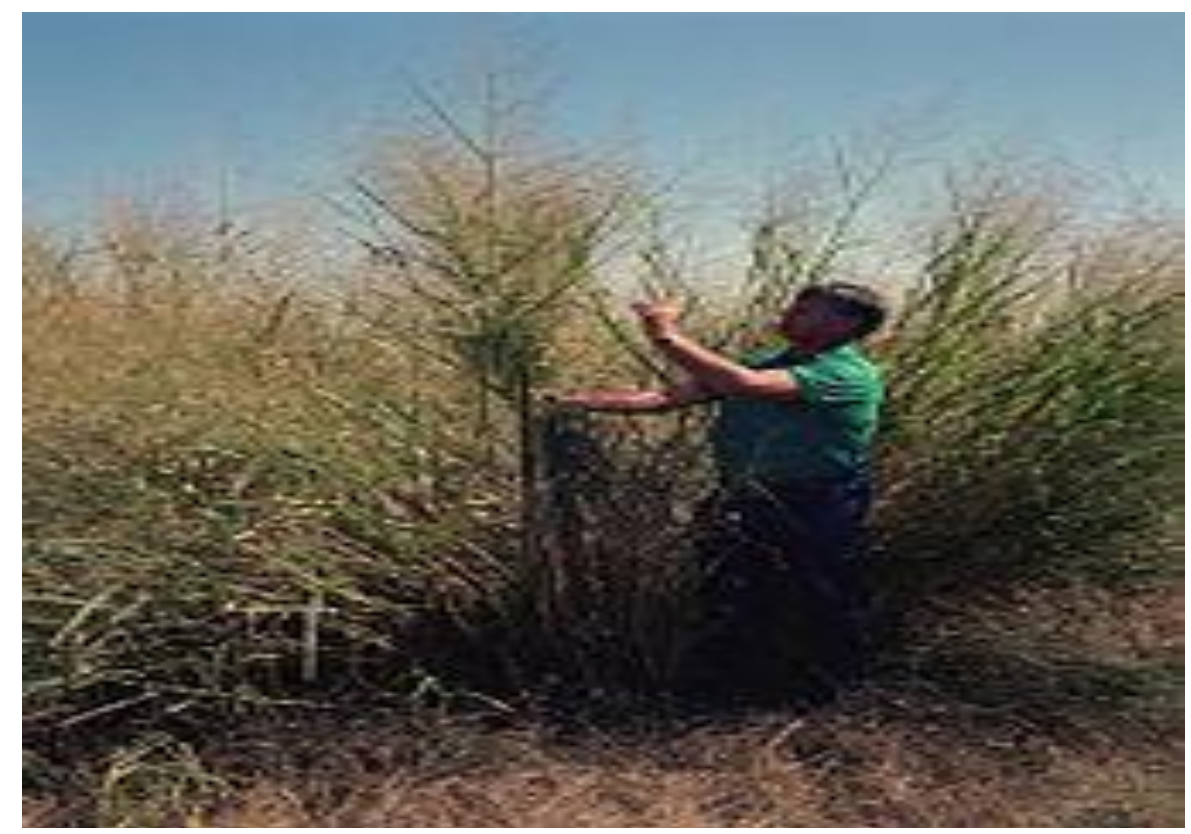

Switch grass 


\section{CONCLUSION}

Ethanol as a gasoline blend has helped to reduce dependence on oil import and harmful vehicular emission and improve the rural economy. Since ethanol is produced from biomass such as sugarcane, molasses and grains, its widespread use has led to higher biomass, yields, rural employment and growth in industry.

Ethanol use reduces $\mathrm{CO}$ and $\mathrm{HC}$ emission from the two and three wheeler segment including other LCV/HCV will find a useful alternative.

India has large potential of renewable energy sources such as Biogas, Solar. Wind, Small Hydropower and Ocean energy. The effective utilization of these depends on the availability of resources.

Of the alternative, Methanol is toxic and so poses a health hazard and while it may be safer in a crash, it corrodes engines. Ethanol would seem to after the best combination of convenience and safety of any liquid fuel. Although a car needs a slightly larger fuel tank to give the same range between fillings. It does not present any difficulties with existing car engines and when it burns, it provides very little in the way of pollution.

However, the Government of India has completely ignored ethanol in its entire programme for implementation, but do we have a choice.

\section{ADDITIONAL APPROACHES (METHANOL}

\section{MANIA):}

In terms of cost, ethanol does no longer compete with petrol. Therefore, Brazilian governments buying the electricity generated by burning sugar cane residues, farmers increasing sugar cane yields and manufacturers were boosting alcohol production by 15 percent. Ethanol is still used because as a so-called oxygenated fuel, it produces less pollution. Methanol Mania was once produced by heating wood chips, which is why it used to be called wood alcohol. Today, it is made from synthesis gas, which can be converted into methanol by means of a catalyst of Zinc oxides and Chromium.

Methanol is a volatile liquid, which at $65^{\circ} \mathrm{C}$ and can fuel car engine. Unlike petrol, it does produce a fireball when ruptured fuel tank catches fire in a crash. Most unleaded petrol contains 5\% methanol, on its derivatives methylteeritary butyl either (MTBE).

World demand for methanol now exceeds 20 million tones 10 years ago. Methanol can also be used in fuel calls to generate electricity.

Methane is also a renewable resource and is a major by product of sewage. It is generated in any organic matter that is decomposed in airless condition by anaerobic bacteria.
Methane, which accounts for between 85 and 99 percent of natural gas by volume, is already used as a fuel for transport and is supplied in cylinders. Around the world half a million vehicles run on so-called CNG mainly in Italy, Canada and New Zealand.

Vast deposit of methane are locked away below the permafrost of Siberia and else where and in many ocean sediments, trapped in ice crystal gas hydrates. The crystals are 12 percent methane and total reserves may be as much as five million trillion $\left(10^{13}\right)$ Cubic meters.

These may never be needed because methane is also a renewable resource and is a major by product- by- product of sewage. It is generated in any organic matter that is decomposed in airless conditions by anaerobic bacteria. Methane can be extracted from decaying matter in rubbish tips. Both sources could be used to produce CNG after treatment to upgrade the quality of the gas recovered. It comes mixed with carbon dioxide and nitrogen, which have no energy value. While the methane could be separate and solid as CNG. It is much easier just to burn effluent gas to produce heat or to turbine to generate electricity.

Other organic wastes, such as crop residues, could also be digested to yield methane, or they could be converted to liquid fuels. A lot of energy can be reclaimed by burning municipal waste as fuel in incinerators.

There are also schemes to convert waste into oil. It has been shown that mixing the waste withy the hydrocarbons solvent tetralin and heating under a pressure of hydrogen gas at 450 ' $\mathrm{C}$ for an hour will convert 90 percent of the plastic into light oil. Unlike ordinary crude oil, it is free of sulphur and is therefore, easier to refine. BP Chemicals has found that a better way is to use a special reactor called a fluidized sand bed, which can turn almost all types of plastic into useful hydrocarbons. The plastics are heated at 400 to $600^{\circ} \mathrm{C}$ and decomposed to give off a mixture of petrol, diesel and paraffin.

Other wastes that can yield fuel are sawdust, newspaper and sewage. Heat and pressure will convert the cellulose from sawdust and newspapers into oil, mimicking the process that first produced fossil fuels-such as coal and gas-from ancient vegetations deep within the Earth's crust. When bacteria digest sewage in the absence of air, they generate methane gas. This is used in Europe as a fuel to generate electricity.

Sewage can also be turned directly into oil by a process in which sewage sludge is made alkaline and heated under pressure. This converts the organic material to crude oil, water and carbon dioxide 


\section{REFERENCES}

[1] Project of Fast Track proposals in Department of Science \& Technology, Govt. of India, N.Delhi, as Young Scientist, Ref. No. File No. SR/FTP/ET13/2001, dated 03.08.2001, of Dr. Porag Kalita, M.R.S .Higher secondary school, Titabor, Assam.

[2] Proceeding of SAE International Total Life Cycle Conference \& Exposition in Michigan, USA, 2000. (SAE the Engineering Society for Land/Sea/Air and Space vehicles, H.Q. USA.

[3] Bulletin by IMI, (Institute of Motor Industry) Chennai, 1994.

[4] Paper by Dr. Kalita P, 47 ${ }^{\text {th }}$ Assam Science Society Technical conference was held Regional Medical Research Center (ICMR), Dibrugarh, Assam, Abstract pages No. 14, in Chemical Science Division.

[5] SAE paper no. 2000-01-1414 by Prof. Murthy, IIT, and Chennai.

[6] SAE paper no. 2000-01-1477 by Dr.Porag kalita, M R S Higher Secondary School, Titabor, Assam.

[7] Proceeding of SAE 2000 World Congress, USA. ( www.sae.org.).

[8] SAE 2000 Ethanol vehicle Challenge, ISBN 0-76800765-8

[9] 2001 SAE Fuel Cell Power for Transmission, ISBN0-7680-0736-4.

[10] Automotive Service Business, Volume I, a Book by Dr. Porag Kalita.

\section{DEFINITION/ ACRONYMS /ABBREVIATION}

\section{Definition}

1) Crankpins: The small boss of an engine cranks which carries the crank pins.

2) Crankshaft: The main engine shaft, driven round by the pistons.

3) Cylinder: (a) A solid generated by a straight line moving round a closed curve moreover, remaining parallel to a given direction.

(b) The cylindrical (Tubular) chamber in which the piston of an engine or pump reciprocates.

4) Detonation: When petrol of very low octane rating rapidly burns inside the combustion chamber, it gives rise to a metallic sound. Referred as knocking, it may also be caused due to over advanced ignition timing.

5) Firing order: The order in which firing takes place in the various cylinders of the engine.

6) Paraffin: Paraffin's are saturated hydrocarbons having the formula $\mathrm{C} 2 \mathrm{H} 20+2$. The lower paraffin's are gases and the still higher is solid.

\section{Acronyms:}

1) Ideal Otto Cycle: Nicolas Argust Otto, an engineer succeeded in working an engine on the four-stroke cycle. The cycle consists of two constant volumes lines and two reversible adiabatic lines to give maximum theoretical Pressure.
2) Actual Otto Cycle: A working cycle of a four-stroke piston engine with suction, compression, explosion at constant volume, expansion and exhaust. This involves heating and reversible cooling at constant system.

3) Soot Particles: Carbon soot is generated in the cylinder during the combustion process. All soot has a graphite structure with hexagonal basis carbon units forming a small crystalline atom.
Abbreviation:
1) $\quad \mathrm{CNG}$ : Compressed Natural Gas.
2) LCV : Light Commercial Vehicle.
3) MTBE : Methyl tertiary butyl either.
4) HCV : Heavy Commercial Vehicle.
5) RME : Rape methyl Ester. 